\title{
Myofibroma of the oral cavity. A rare spindle cell neoplasm
}

\author{
Bernardo-Ferreira Brasileiro ${ }^{1}$, Paulo-Ricardo-Saquete Martins-Filho ${ }^{1}$, Marta-Rabello Piva ${ }^{1}$, Luiz-Carlos- \\ Ferreira da Silva ${ }^{1}$, Cassiano-Francisco-Weege Nonaka ${ }^{2}$, Márcia-Cristina-da Costa Miguel ${ }^{2}$
}

\author{
${ }^{1}$ Department of Oral Pathology, Dentistry School, Federal University of Sergipe, Sergipe, Brazil \\ ${ }^{2}$ Department of Oral Pathology, Dentistry School, Federal University of Rio Grande do Norte, Rio Grande do Norte Brazil
}

\author{
Correspondence: \\ Universidade Federal de Sergipe \\ Campus da Saúde \\ "Prof. João Cardoso Nascimento Júnior" \\ Departamento de Odontologia \\ Rua Cláudio Batista, s/n. Bairro Sanatório \\ CEP: 49060-100. Aracaju, SE, Brazil \\ saqmartins@hotmail.com
}

Received: 13/05/2009

Accepted: 28/11/2009

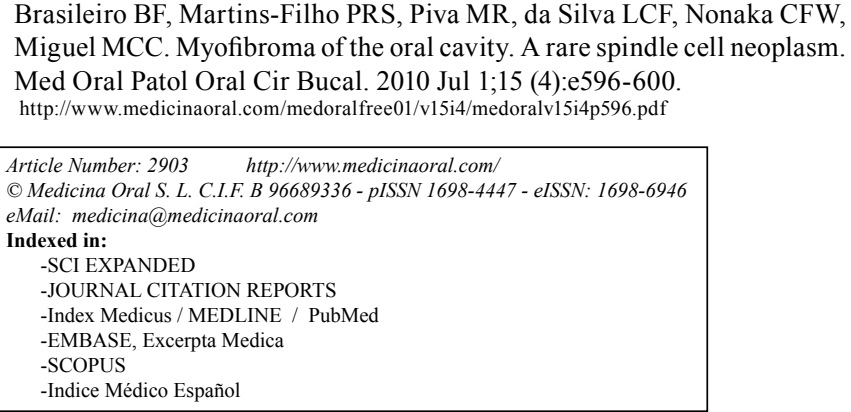

\begin{abstract}
Myofibroma is an uncommon spindle cell neoplasm rarely found in oral cavity. Typically, this lesion is seen in neonates and infants with few cases reported in adults patients. In the oral cavity, myofibroma occurs within the submucosal or intramuscular tissue and has a predilection by the tongue, buccal mucosa and lips. Microscopically, a typical biphasic pattern can be observed. Misdiagnosis included benign and malignant spindle cell lesions of nerve tissue or smooth muscle origin, such as neurofibroma, leiomyoma and sarcomas. Thus, immunohistochemical staining is a useful tool to identify the nature of neoplastic cells and to reach an accurate diagnosis. An immunohistochemical panel consisting of antibodies to vimentin, SMA, HHF-35, S-100p and desmin must be achieved. In most cases, positivity for vimentin, SMA and HHF- 25 can be observed. Our report describes a solitary myofibroma of the tongue of a 23-year-old man with emphasis in clinical, histopathological and immunohistochemical features of this lesion.
\end{abstract}

Key words: Myofibroma, oral, soft tissue.

\section{Introduction}

Myofibroma is a rare, benign mesenchymal tumor, most of which develop in infancy or before the age of 2 years. It was first described by Stout (1) in 1954 as congenital generalized fibromatosis and renamed as infantile myofibromatosis by Chung et al. (2) in 1981. The last name reflected the typically young age at onset of this disease and the myofibroblastic nature of the neoplastic cells. However, Smith et al. (3) later introduced the term my- ofibroma to note that such lesions were most commonly solitary and not exclusively pediatric. According Chung et al.(2), about one-third of all myofibromas occur in head and neck, with few cases reported in oral soft tissues. This communication describes a solitary myofibroma of the tongue of a 23-year-old man with emphasis in clinical, histopathological and immunohistochemical features of this lesion. 


\section{Case Report}

A 23-year-old man visited the Department of Oral Pathology, Federal University of Sergipe, Brazil, for evaluation of a painless swelling on the tongue present for approximately 7 months. The patient denied any dysphagia, odynophagia, difficulty breathing or swallowing. The medical history and review of symptoms were noncontributory. There was no history of similar lesions in the patient or members of his family. Intraoral examination revealed a firm, localized swelling in the left posterior tongue border. The overlying mucosa was of normal color and ulceration was not noted.

The patient was admitted for surgical intervention and the lesion was excised under general anesthesia. Macroscopic examination revealed off-white ovoid firm mass with a homogenous texture measured $1.5 \mathrm{~cm}$ in its greatest dimension (Fig. 1). Microscopic examination of 5 . sections stained with hematoxylin and eosin (HE) revealed a well-circumscribed tumor composed of spindle-shaped cells arranged in a biphasic pattern. The periphery of the tumor contained more mature spindleshaped cells in an interlacing pattern. These spindleshaped cells were large and elongated with eosinophilic cytoplasm and oval tapering-end nuclei. Nuclear atypia and mitotic figures were not seen. The central portion of the lesion contained more immature-appearing cells with hemangioperycitoma-like pattern (Fig. 2).
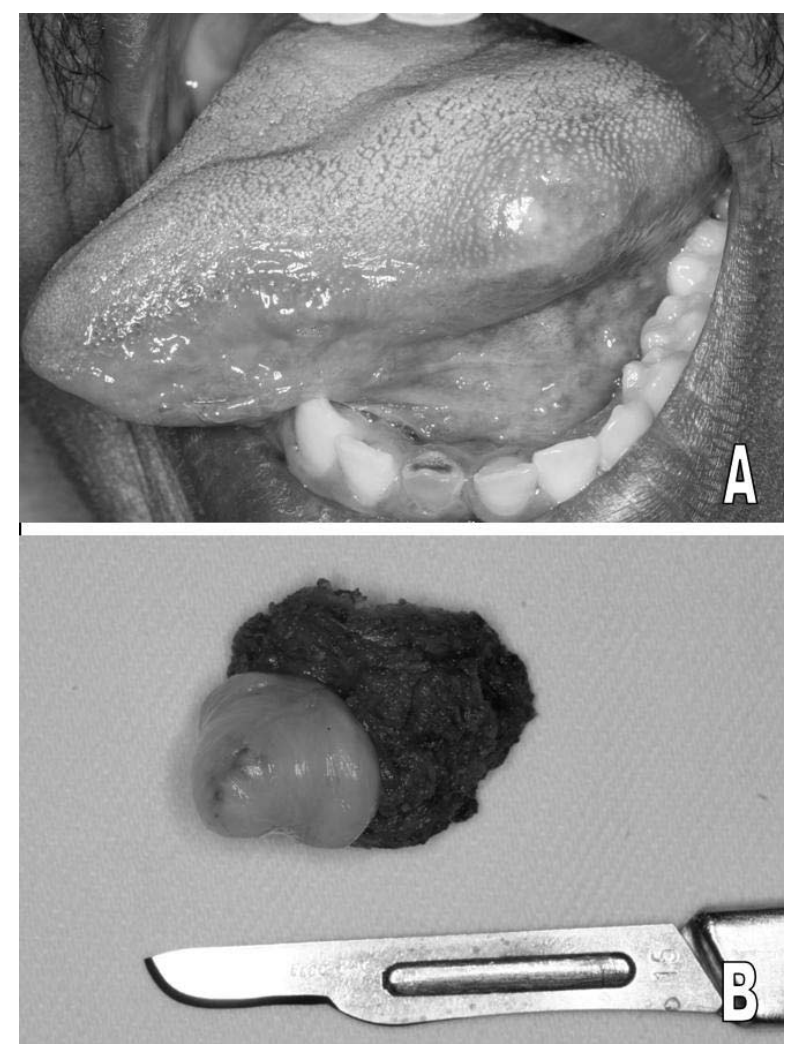

Fig 1. A, Clinical presentation of myofibroma. A submucosal nodule in the left posterior tongue border. B, gross examination of myofibroma after excision.
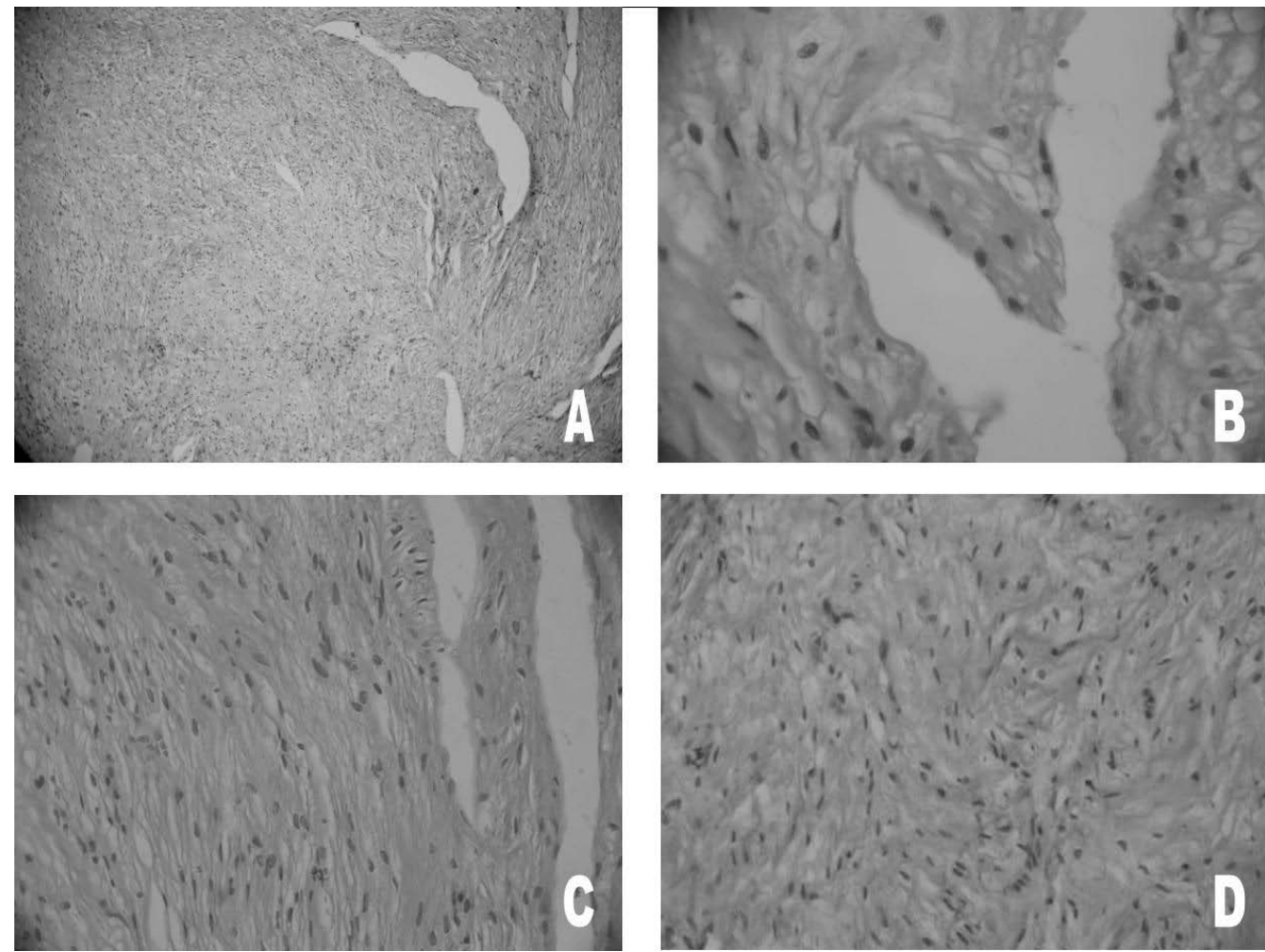

Fig 2. Histologic features of myofibroma (hematoxylin-eosin stain). A, the tumor cells exhibiting a biphasic pattern (original magnification $\mathrm{x} 50$ ). $\mathrm{B}$, higher power view showing an area with hemangiopericytoma-like pattern of the blood vessel (original magnification $\mathrm{x} 500$ ). C, photomicrography showing the large elongated cells with tapering ends (original magnification x100). D, interlacing fascicular arrangement of myofibroblast closely resembling smooth muscle tumor (original magnification x100). 

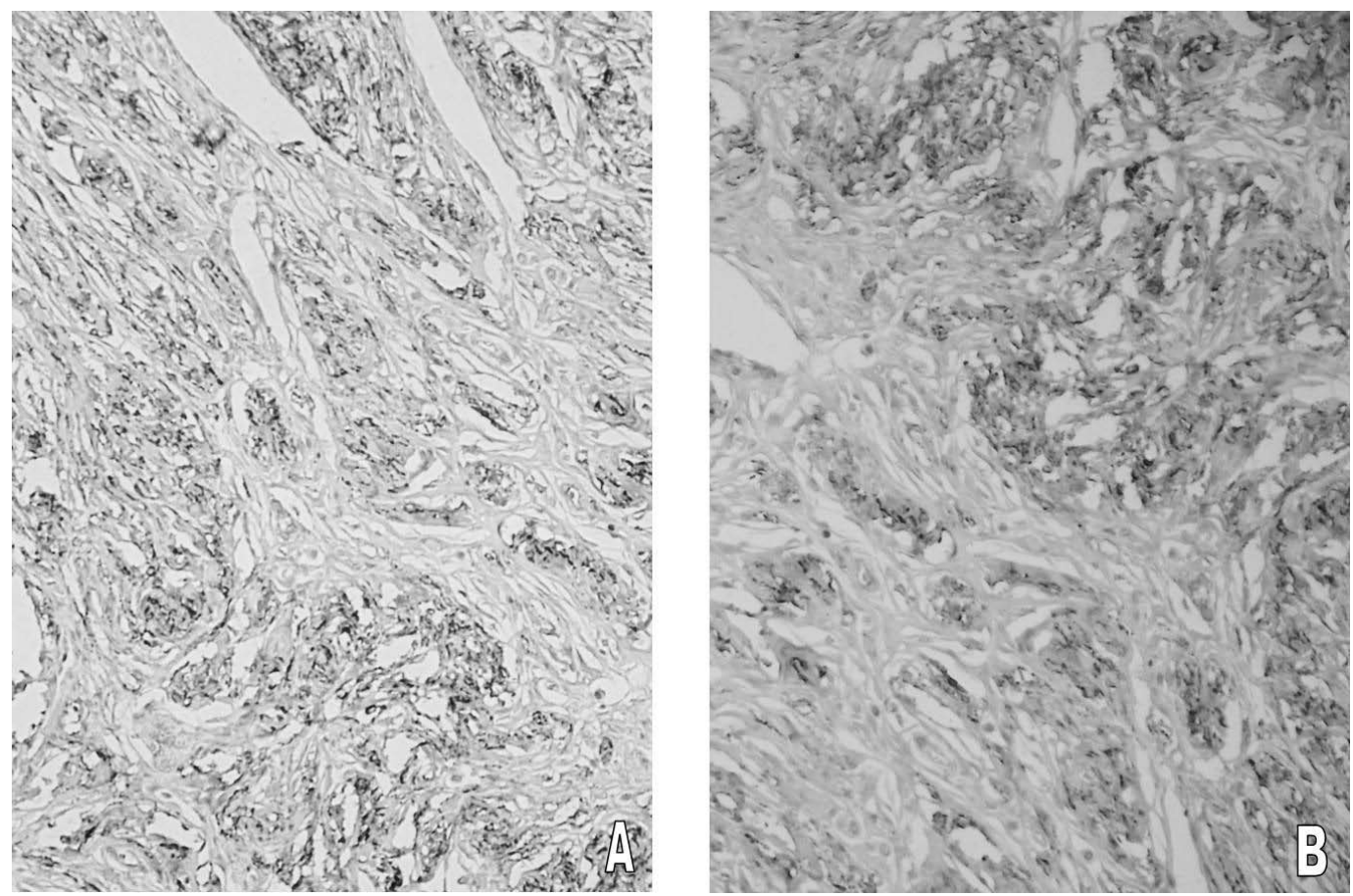

Fig 3. Immunohistochemical staining reveals the strong expression of smooth muscle actin (original magnification $\mathrm{A}$, $\mathrm{x} 200$ and $\mathrm{B}, \mathrm{x} 400)$.

Immunohistochemical staining showed positivity for vimentin and smooth muscle actin (SMA), but was negative for desmin and S-100p (Fig. 3). On the basis of histopathologic and immunohistochemical features, final diagnosis of myofibroma was rendered. The patient has shown no signs of recurrence 2 years after surgery.

\section{Discussion}

Solitary myofibroma is a rare benign spindle cell neoplasm that may arise in the skin, subcutis, soft tissue, bone, and, exceptionally, in viscera. In the head and neck, the most frequent site is bone, followed by buccal mucosa and tongue (4). According Jordan and Regezi (5), the prevalence of solitary myofibroma in the oral cavity is very low. The authors reviewed 307 nonodontogenic spindle cell neoplasms accessioned over a 20 -year period from an oral pathology service and observed that only 8 cases were diagnosed as myofibroma. In a recent review of English language literature, Vered et al. (6) found only 41 cases of oral soft tissue myofibroma.

Typically, this lesion is seen in neonates and infants with few cases reported in adults patients. In the oral cavity, the tumor frequently occurs within the submucosal or intramuscular tissue and has a predilection by the tongue, buccal mucosa and lips. Clinically, these are usually slow-growing painless soft tissue swellings with an intact mucosa unless secondarily ulcerated (7). They typically range in size from 0.5 to $5.0 \mathrm{~cm}(8)$.

Surgical excision is the treatment of choice for myofibroma. The prognosis of this rare tumor is excellent after conservative surgical curettage or resection (9). According Daimaru et al. (10), the recurrence rate is only $7 \%$ after excision. In agreement with previous reports, there was no evidence of recurrence after over the two years of follow-up.

Gross examination revealed a well-delimited mass that varied from white to pinktan to gray with a firm or gritty consistency (8). Three cell types can be recognized on the electron microscopic examination: myofibroblast-like cells, fibroblastic-like cells and intermediate cells. A majority of the tumor cells are composed by intermediate cells type and myofibroblastic-like cells had cytoplasmatic filaments with dense bodies, basal lamina, pinocytotic vesicles and nuclear invaginations (9). However, electron microscopic evaluation of tumor specimens is not routinely used in most pathology services. In the current case, definitive diagnosis was made on the basis of the histopathological and immunohistochemical findings.

Microscopically, a typical biphasic pattern can be observed. Peripheral zone of myofibroma is composed of spindle-shaped cells with long oval nuclei and abundant eosinophilic cytoplasm that resembled smooth muscle. 
Table 1. Immunoreactivity for antibodies in oral myofibromas.

\begin{tabular}{|l|c|c|c|c|c|c|c|}
\hline \multicolumn{1}{|c|}{ Authors } & Year & Cases & SMA & Vimentin & S-100p & Desmin & HHF-35 \\
\hline Jones et al. (12) & 1994 & 12 & + & + & - & - & ND \\
\hline Lingen et al. (4) & 1995 & 4 & + & + & - & - & ND \\
\hline Sugatani et al. (9) & 1999 & 1 & + & + & - & - & ND \\
\hline Montgomery et al. (13) & 2000 & 9 & + & ND & - & - & ND \\
\hline Jordan, Regezi (5) & 2003 & 8 & + & ND & ND & - & ND \\
\hline Scheper et al. (7) & 2005 & 1 & + & ND & - & ND & ND \\
\hline Azevedo et al. (11) & 2008 & 2 & + & + & - & - & + \\
\hline
\end{tabular}

ND not described.

Central portion of this tumor comprise a population of more primitive spindle cells associated with a hemangiopericytoma-like vascular pattern $(7,9)$. In rare cases, reversal of typical zonation as well as necrosis and calcification can be observed (11). In current case, there was no necrosis and calcification, but multiple slit-like vascular spaces resembling hemangiopericytoma.

Immunohistochemical staining is a useful tool to identify the nature of neoplastic cells and to reach an accurate diagnosis. An immunohistochemical panel consisting of antibodies to vimentin, S-100p, desmin, HHF-35 and SMA must be achieved (4,5,7,9, 11-13) (Table 1). Vimentin is the most widely expressed intermediate filament protein thought to be involved in structural processes. This protein is a general marker of cells originating in the mesenchyme and is frequently included in the socalled primary panel together with others antibodies such as cytokeratins, neurofilaments, S-100 and desmin. Intense staining reaction for vimentin without coexpression of other intermediate filament proteins is strongly suggestive of a mesenchymal tumor such as sarcomas and lymphomas (14).

$\mathrm{S}-100 \mathrm{p}$ is an acidic nuclear protein specific for the nervous system that regulates intracellular processes such as cell growth and motility, cell cycle regulation, transcription and differentiation. This protein is often used in the differential diagnosis of tumors of neural origin (5).

Desmin is as intermediate filament protein of both striated and smooth muscles useful in identification of tumors of myogenic origin, such as myofibrosarcomas, leiomyosarcomas and rhabdomyosarcomas (8). HHF35 , a muscle-actin specific monoclonal antibody, has also been used as a marker for soft tissue tumors with muscle differentiation, for which it displayed a higher degree of sensitivity than desmin antibodies. HHF-35 reacts with skeletal muscle cells, cardiac muscle cells, smooth muscle cells, pericytes and myoepithelial cells, but is nonreactive with endothelial, neural or connective tissue cells (15). Some authors have used this marker recently in diagnosis of myofibroma (11).

Smooth muscle actin expression is the most used mark- er for myofibroblast identification. Foss et al. (8) examined immunohistochemically 39 cases of oral myofibroma and verified $100 \%$ positivity for this protein. In our case, positive staining for smooth muscle actin was obtained, confirming the myofibroblastic origin of the tumor.

Misdiagnosis included benign and malignant spindle cell lesions of nerve tissue or smooth muscle origin, such as neurofibroma, leiomyoma and sarcomas. Thus, knowledge about myofibroma is important to establish the correct diagnosis and avoid morbidity of unnecessary aggressive therapy (11).

In summary, because of the scarcity of smooth muscle in the oral cavity, the myofibroma is a relatively uncommon lesion in that location. The tumor can be present as slowgrowing, asymptomatic, firm submucosal swelling that is rarely ulcerated. Immunohistochemistry is a valuable, precise and reliable method for establishing a definitive diagnosis of this lesion.

\section{References}

1. Stout AP. Juvenile fibromatoses. Cancer. 1954;7:953-78.

2. Chung EB, Enzinger FM. Infantile myofibromatosis. Cancer. 1981:48:1807-18.

3. Smith KJ, Skelton HG, Barrett TL, Lupton GP, Graham JH. Cutaneous myofibroma. Mod Pathol. 1989;2:603-9.

4. Lingen MW, Mostofi RS, Solt DB. Myofibromas of the oral cavity. Oral Surg Oral Med Oral Pathol Oral Radiol Endod. 1995;80:297302 .

5. Jordan RC, Regezi JA. Oral spindle cell neoplasms: a review of 307 cases. Oral Surg Oral Med Oral Pathol Oral Radiol Endod. 2003;95:717-24.

6. Vered M, Allon I, Buchner A, Dayan D. Clinico-pathologic correlations of myofibroblastic tumors of the oral cavity. II. Myofibroma and myofibromatosis of the oral soft tissues. J Oral Pathol Med. 2007;36:304-14.

7. Scheper MA, Difabio VE, Sauk JJ, Nikitakis NG. Myofibromatosis: a case report with a unique clinical presentation. Oral Surg Oral Med Oral Pathol Oral Radiol Endod. 2005;99:325-30.

8. Foss RD, Ellis GL. Myofibromas and myofibromatosis of the oral region: A clinicopathologic analysis of 79 cases. Oral Surg Oral Med Oral Pathol Oral Radiol Endod. 2000;89:57-65.

9. Sugatani T, Inui M, Tagawa T, Seki Y, Mori A, Yoneda J. Myofibroma of the mandible. Clinicopathologic study and review of the literature. Oral Surg Oral Med Oral Pathol Oral Radiol Endod. 1995;80:303-9.

10. Daimaru Y, Hashimoto H, Enjoji M. Myofibromatosis in adults 
(adult counterpart of infantile myofibromatosis). Am J Surg Pathol. 1989;13:859-65.

11. Azevedo Rde S, Pires FR, Della Coletta R, de Almeida OP, Kowalski LP, Lopes MA. Oral myofibromas: report of two cases and review of clinical and histopathologic differential diagnosis. Oral Surg Oral Med Oral Pathol Oral Radiol Endod. 2008;105:e35-40.

12. Jones AC, Freedman PD, Kerpel SM. Oral myofibromas: a report of 13 cases and review of the literature. J Oral Maxillofac Surg. 1994;52:870-5.

13. Montgomery E, Speight PM, Fisher C. Myofibromas presenting in the oral cavity:a series of 9 cases. Oral Surg Oral Med Oral Pathol Oral Radiol Endod. 2000;89:343-8.

14. Osborn M. Intermediate filaments as histologic markers: an overview. J Invest Dermatol. 1983;81:104s-9s.

15. Tsukada T, Tippens D, Gordon D, Ross R, Gown AM. HHF35, a muscle-actin-specific monoclonal antibody. I. Immunocytochemical and biochemical characterization. Am J Pathol. 1987;126:51-60. 